\title{
Kentsel Dayanıklılık Odaklı Planlama Yaklaşımının Türk Kent Planlama Sistemine Uyarlanması
}

\author{
Zeynep Deniz YAMAN GALANTINi ${ }^{1}$
}

Öz

Kent planlama pratikleri, günümüzün beklenmedik değişikliklerinin belirsiz sonuçlarıyla baş edememektedir. Bu noktada dayanıklılık, sürekli gelişme, uyum sağlama ve beklenmedik değişikliklerle nasıl yaşanacağını öğrenmeyi vurgulayan çağımızın öncü kavramı olarak, kent planlama literatürüne girmektedir. Dayanıklıığın bu dinamik karakteri göz önünde alındığında, kent planlamanın temel unsurlarının dayanıklılık perspektifinden vurgulanmasının önemi 2000'li yıllardan beri hızla artmaktadır. Bu nedenle kentsel dayanıklıık planlamasının mevcut bir kentsel planlama hiyerarşisine nasıl dâhil edilmesi gerektiğini tanımlamak ve ardından kentsel dayanıklılık planlamasının bir yasama sisteminde nasıl konumlandırılabileceğini açıklamak, tartışıması gereken temel sorgulama alanlarındandır. Buradan yola çıkarak bu makale, Türkiye örneği üzerinden dayanıkııık temelli yasal çerçeve ve kent planlama süreci tanımlamayı amaçlamaktadır ${ }^{2}$. Bu çalışmada İstanbul'da uygulanan Uzman Anketi, iki aşamalı Politika Delphi Anketi ve Halk Anketi'nin sonuçları üzerinden, mevcut kent planlama süreci için gerekli güncelleme ve iyileştirmeyi sağlayacak "beş bileşenli planlama süreci" tanımı yapılmaktadır. Ayrıca, beklenmedik değişiklikleri yönetme kapasitesindeki boşluğu doldurmak amacıyla, dayanıklıığı mevcut kent planlama hiyerarşisine ve yasama sistemine dâhil edecek bir öneri sunulmaktadır.

Anahtar Kelimeler: Kentsel dayanıklılık planlaması, Türk kent planlama sistemi, dayanıklılık temelli yasa ve kent planlama sistemi.

\section{Introducing \& Adapting "Urban Resilience Planning" to Turkish Urban Planning System}

\begin{abstract}
Due to the unexpected changes, planning theory couldn't cope with their uncertain implications. At this point, resilience is the pioneer concept of this era which stresses to learn how to live with unexpected changes in the face of disturbances while developing continuously, adapting to or transforming into a better state. Considering this dynamic character of resilience, urban resilience-urban planning studies have been rising since 2000s with different interpretations to emphasize an advancement of urban planning's basic elements through the resilience lenses. Here, the most fundamental outcomes to be discussed are, firstly, to define how urban resilience planning should be included in an

\footnotetext{
1 TCDD 1. Bölge Müdürlüğü, Emlak Müdürlüğü, İstanbul, Türkiye

2 Makalede sunulan öneriler, "Urban Resilience as A Policy Paradigm for Sustainable Urban Planning and Urban Development: The Case of Istanbul" başlıklı doktora tezinin ampirik kısmına dayanmaktadır.

*ilgiliyazar / Corresponding author: yamanzede@gmail.com

GönderimTarihi / Submission Date: 18.09.2020
}

Kabul Tarihi / Acception Date: 24.12.2020
\end{abstract} Uyarlanması. Resilience, 4(2), 347-371. 
existing urban planning hierarchy and then, to define how to position urban resilience planning in a legislative system. Starting from this perspective, this paper aims to highlight the plausible resilience-related legislative and urban planning system through Turkey case. The paper not only reflects the outcomes of an Expert Questionnaire, two-stage Policy Delphi Survey and Public Survey applied in Istanbul, but also proposes "five elements process" as a required upgrade for the existing urban planning process. Moreover, a suggestion to integrate resilience into the existing urban planning hierarchy and legislative system were made to fill the gap of the capacity to manage uncertain changes ${ }^{3}$.

Keywords: Urban resilience planning, Turkish urban planning system, resilience-related legislative and urban planning system.

\section{Introduction}

The main issue that needs to be discussed in order to resolve today's rapidly changing and growing urban problems is to explain how urban planning should be updated in order to contribute to the effective solution of urban vulnerabilities caused by uncertainties and complexity. Considering the increasing role of change, variable dynamics and uncertainties (Novotny et al. 2010), it can be concluded that there is no guarantee that cities will exist forever. Although urban sustainability aims to make cities livable for people indefinitely, ensuring this condition has not always been easy. Economic, ecological or social stability can never be achieved forever (Wikström, 2013), and the complex systems of cities exhibit nonlinear behavior under the influence of uncertainties (Zhao et al.2013). In this context, it's vital for all cities to analyze physical, environmental, social, economic and institutional systems well and to maintain "continuous development and adaptation in the face of changing conditions". In other words, in the rapidly changing and increasingly complex world, individuals, institutions and societies must have a structure that can cope with changes, adapt to changes and shape changes. This approach overlaps with the concept of "resilience", which tries to explain how to deal with the changes and challenges of the uncertain world.

Resilience has been in the literature since $18^{\text {th }}$ century and has been a basis for many studies from ecology to microbiology. In general terms, "resilience" is a concept that develops in the direction of understanding and managing complex relations between human and nature. It has been used primarily in the field of ecology and then in different perspectives related to the city after 1970s, and its relationship with urban planning attempted to be established in 2000s. Urban resilience is defined not only as the ability of cities to respond to changes, but also as a state of being flexible and robust against unpredictable and unexpected situations (Holling, 2001; Alberti et al. 2003; Berkes, Folke, \& Colding, 1998). In this context, urban resilience is considered as a multidimensional approach that enables the successful management of the change that cities are exposed to. Therefore, ensuring resilience can be defined as an indispensable priority for cities.

There is no clear method on how to link urban planning with resilience. First of all, one of the most important features that make it necessary and important to associate resilience with urban planning and interpret an "urban resilience planning process" is the purpose of defining a system that is "ready for unexpected changes". At this point, two basic points that need to be emphasized are 1. the necessity of developing the "coping capacity" in order to ensure stability and direct change, 2. although global challenges have an impact on all cities, resilience-based urban planning must be defined as "city-specific", as their consequences or

\footnotetext{
${ }^{3}$ The outcomes are based on the empirical part of the PhD thesis titled "Urban Resilience as A Policy Paradigm for Sustainable Urban Planning and Urban Development: The Case of Istanbul".
} 
severity differ in all cities. This necessitates primarily the definition of "what must be developed to obtain resilience" for each city individually. In other words, establishing the relationship between resilience and urban planning obliges to explain what is expected from "urban resilience", what the characteristics of a "resilient city" should be, or what conditions urban planning must provide for being resilient. Considering the dynamic character of resilience, each city has "changing goals" and accordingly "changing resilience potentials" that should be taken into account in different periods. With this regard, it's crucial to define; 1. "Resilience to what" (what are the most important vulnerabilities/issues that are needed to be addressed urgently; 2. "Where" (where/at what scale resilience should be provided first) and 3."How" (what should be the main components of the "urban resilience planning" framework. Yaman-Galantini (2018) described "Five Elements Process" to clarify these three complementary components of resilience through the relations between the five elements of urban resilience planning process.

The elements in this process can be listed as "stakeholders, scale, interdependencies, resilience qualities (indicators), planning tools and policies". The underlying idea is to define a comprehensive urban planning process scheme from national to local scale, as well as the most appropriate governance plan and ideal actor mapping. Therefore, the first element referring to "stakeholders" aims to identify actors who should be involved in the urban resilience planning process. The "scale" is another component of the process that defines the most vulnerable areas and key vulnerabilities that require urgent intervention. The "attributes of resilience" defined as "indicators" are the components that facilitate measurement and mapping. In the meantime, it would be more beneficial to shape the basic urban policies by considering the "interdependencies" of all urban components, i.e. their interaction with each other, seeing the whole rather than evaluating them separately. Thus, finally, the element of "planning tools and policies" determines which urban resilience policies can be developed and which tools can be implemented in order to define prior policies. Each element of the five elements process refers to the "resilience to what", "where" and "how" components of the urban resilience planning framework (Figure 1).

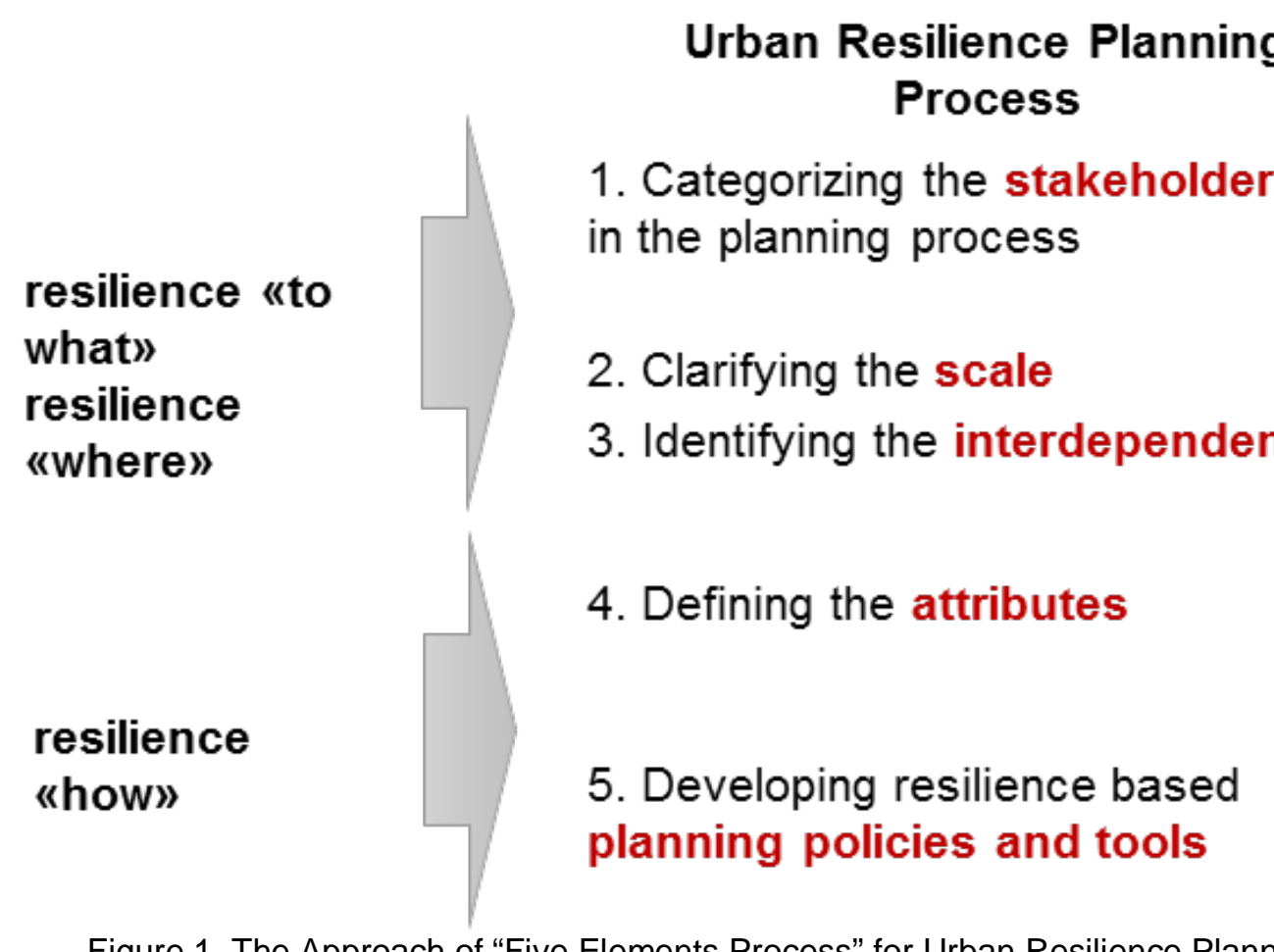

Figure 1. The Approach of "Five Elements Process" for Urban Resilience Planning 
In order to apply five elements process, the starting point is the determination of who should be on board -the stakeholders. There is one more sin a qua point which as Müller (2010) states, one dimension of resilience highlights the ability of the society to learn, adapt and reorganize the way they cope with urban challenges. So, the society should participate to the urban planning decision making process and planners should be aware of the perceptions of all related stakeholders. This clarification can easily be portrayed as "actor-mapping" which creates an opportunity to formulize the actor analysis and to enhance the quality of the participation. In addition, it's going to help to figure out how each actor can contribute to the planning process, what roles they can have and which resources they can mobilize. Under these circumstances, Yaman-Galantini (2018) proposed that the process initiates with an "Expert Opinion" as an appropriate method applied to the scientific researchers working in urban planning field in universities in order to identify the stakeholders at the local and macro level to take part in the urban resilience planning process. As Gotham and Campanella (2010) explain, there are a variety of diverse organizations, social networks, institutions, and actors with changing degrees of political power and access to resources in order to explore the resilience at different scales. So, asking to urban planning academicians as experts could create a macro evaluation about the ideal participation model.

At this point to gather experts' opinions to build consensus in the policy decision process, two-stage "Policy Delphi Survey" can be applied. This method is chosen because it's a qualitative forecasting technique, which is applied when forecasted events cannot be explained through quantifiable information (Cornel and Mirela, 2008). Additionally, as Yousuf (2007) declares it's a method of last option in dealing with extremely complex problems for which there are no adequate models. First step initially aims to find the key vulnerabilities and the most vulnerable places, specifically "to what" and "where" resilience should be obtained. The participants weight the key vulnerabilities and policies addressing them.

After the justification of most vulnerable places, a "Public Opinion Survey" can be conducted to understand how the citizens of the selected vulnerable places perceive the vulnerabilities/threats that they may face to, in accordance with what they expect from resilience based policies. This method generates public participation. All the answers from the Public Opinion Survey and the first step of Policy Delphi Survey together were evaluated by "multi-criteria analysis" to measure the resilience level. Then, the second stage of the "Policy Delphi Survey" aimed to develop an urban planning framework as well as urban policies and tools based on resilience principles. In other words, "how" resilience can be developed contingently on the results of the first stage of Policy Delphi and the perceptions/expectations of the citizens obtained from the Public Opinion Survey.

In this context, this paper explains the outcomes of how resilience can adapt to the planning hierarchy and planning system in Turkey through the application of the five elements process in Turkish case. Moreover, paper aims to suggest solutions to the main deficiencies of Turkish urban planning system. It is clear that today; the project-based urban development in Turkey dominates the current urban planning practices since the first decade of $21^{\text {st }}$ century. Laws and their amendments encourage spatial organization or centralization in general and this conflicts with the sustainable development perspective of the policies proposed in the provincial plans. All in all, urban planning practices have failed to control and regulate urban development while investing in only economic vitality in the form of spatial expansion. Besides, a hierarchy and a desired coordination among urban planning actors are missing. Therefore application of the resilience approach will definitely fill these gaps through developing capacity to manage unexpected changes and collaborative decisions of a wide range of urban planning authorities. The first part of the paper describes the current planning system in Turkey. In the next section, the results determined on how the current system will 
internalize the concept of resilience are explained. Finally, in the last section, results regarding how resilience can be included in the legal system are presented.

\section{The Existing Planning Hierarchy in Turkey}

It's possible to state that integrating urban resilience planning in the existing planning hierarchy doesn't necessarily mean to describe new type of urban plans at each scale, but it means to include urban resilience perspective in each type of plan at each level. That makes "urban resilience" an "overall target" of each urban plan. From this perspective, formulating new types of plans or upgrading and updating the existing urban plans in the actual urban planning system can both help to strengthen urban resilience for all aspects of sustainable urban development. All plans upgraded and updated with urban resilience perspective are referred as "urban resilience plans" and the proposed urban planning process as "urban resilience planning process" in this paper. The crucial point is to clarify at which scale it's necessary to formulize new urban resilience plans and which plans can promote urban resilience with an upgrade. Therefore, in order to propose an integration of urban resilience in the urban planning agenda, first of all it's important to explain the existing urban planning system in Turkey.

In Turkey, the current legal basis of the urban planning studies leads to the Law on Land Development Planning and Control (No. 3194) and The Regulation on Spatial Planning (2014) and there are wide-ranging urban plans defined in the Law on Land Development Planning and Control (No. 3194) and The Regulation on Spatial Planning (2014) with a hierarchy from national to local scale. The first group can be classified as "Socio-Economic Plans" that comprise the national development plans and the regional plans as macro level plans. Secondly, there are "Macro Scale Physical Plans" which explains strategic spatial planning decisions while having a physical/blueprint perspective with a more metropolitan or provincial scale. This category includes, "Strategic Spatial Plans, Metropolitan Land Use Plans and Upper-Level/Superior Land Use Plans".

Finally, there are local (micro) level plans which are prepared by metropolitan municipalities or district municipalities, and in some cases Ministry of Environment and Urbanism. These are called "Spatial Plans" comprehending "main physical plans" that are land use and detailed local plans; in addition to "special purpose plans" and "other complementary plans" referring to local scale. Spatial plans are prepared based on the "development legislation (imar mevzuatı)". Land use plans with the scale of 1/5000 are prepared and approved by metropolitan municipalities and are supposed to be appropriate with the macro level plans. These plans include main zone types, future population densities of the zones, building densities as necessary, development direction and magnitude and principles of various settlement areas, transport systems and solutions to transport problems. They also serve as a basis for the detailed local plans. Detailed plans are scaled to 1/1000 and they contain in detail the building blocks of various zones, their density and order, roads and implementation phases to form the basis for land development implementation programs and other information. (Law on Land Development Planning and Control No.3194, 1985). They are prepared and approved by district municipalities. "Special purpose plans" and "other complementary plans" are also local plans having diverse purpose for implementation as indicated in their titles (Figure 2). 


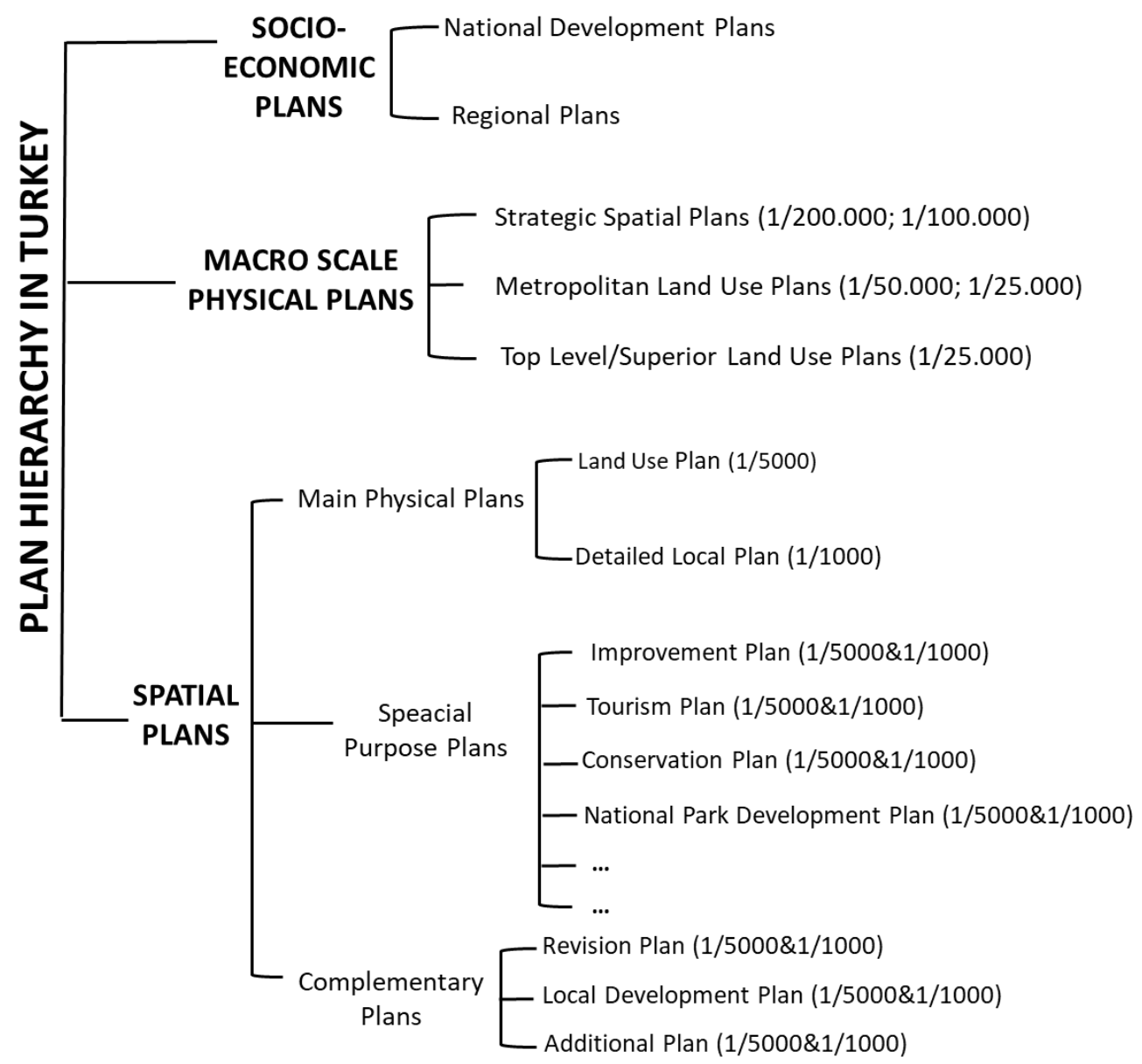

Figure 2. Urban Planning Hierarchy (Developed from Law on Land Development Planning and Control No.3194, 1985 and The Regulation on Spatial Planning, 2014)

The hierarchy among all plan types in our country is explained in the Regulation on Spatial Planning with the principle of "gradual unity between plans" and this necessitates the preparation of each plan in accordance with the decisions of the higher level plans. This means, while preparing metropolitan land use plans, national and regional development plans should be taken into account. Likewise, macro scale plans must form a basis for land use and detailed local plans as well as all other micro scale plans. However, when the applications are examined, it is obvious that plans are prepared without considering the gradual unity principle. This causes lack of holistic approach in eliminating urban problems via urban planning. Such practices also lead to the inability of urban planning practices to "adapt to dynamic processes" and to increasing fragility in cities from local to national scale.

On the other hand, although Article 2 of the Law on Land Development Planning and Control (No. 3194) indicates that the Law on Land Development Planning and Control (No. 3194) is the prior law for making urban plans, there are other laws authorizing many institutions to make plans in various scales. For example, Law on Special Provincial Administration (No. 5302), Mass Housing Law (No. 2985) and Law of Urban Regeneration (Transformation) in Areas under Disaster Risk (No. 6306) are especially important in terms of granting the central government the authority to make and approve plans. All legal instruments which give planning authority to various institutions cause the diversification of planning actors. As a requirement of the "governance" concept, surely, multi-stakeholder participation at different scales in the urban planning process is supported. However, as long as the roles and resources descriptions are not included in the legal regulations, this multi-stakeholder 
participation cannot contribute to anything but confusion. For this reason, it is not possible for "governance" to provide the "capacity to manage unexpected change".

Considering all these highlights, next section discusses how to position urban resilience planning in the existing planning hierarchy in Turkey. First of all, it's useful to understand which content and scale can match more to its general scope. Then, it's possible to describe which content of urban resilience plans can be placed at which point of the hierarchy.

\section{Positioning Urban Resilience Planning in the Existing Planning Hierarchy in Turkey}

\subsection{Evaluating the current urban planning hierarchy through resilience concept}

Starting from the national scale, as Yomralıoğlu and Ülger (2014) expressed, the national development plans is concerned with national goals, allocation of resources and formation of significances for district-level projects which can have impacts on the whole population and wide spread zones. Briefly, they set general principles and concrete development aims and goals in the national level (Türk, 2002). The Ministry of Development is responsible to make national plans which are prepared for five-year period and called "Development Plans". There have been published eleven development plans since 1963, which were prepared for five-year period. The last "Eleventh Development Plan" was released in 2019 (The Ministry of Development, 2019), covering 2019-2023 period. Tenth Development Plan, covering 20142018 period, is the first national plan where "resilience" concept was mentioned as a necessity for construction activities related with disaster management. Moreover, in the Eleventh Development Plan resilience has been mentioned. The relevant highlighted passages can be listed as follows;

- In Turkey, emphasis was given on the policies for the establishment of settlements that are people-oriented, respecting the nature and historical heritage, high quality of life, resilient and where basic urban services are provided in fair and accessible manner and local services are carried out by the subsidiarity principle (pg. 174)

- In order to ensure the sustainable development of cities; the works, such as the establishment of an accessible high-link urban transport system, a disaster- and climate- resilient infrastructure, and a sustainable production and consumption mechanism, long-term integrated urban planning and design, and implementation of effective disaster management, require the participation and comprehensive cooperation of all stakeholders (pg. 174)

- -Quality, safeness, accessibility, energy efficiency and disaster resilience standards will be developed in housing production and will be taken into consideration at every level (pg. 179)

- Disaster risk prioritization of existing infrastructure systems will be carried out and ones needed to be renewed will be done in order to increase urban resilience by taking into consideration the building stock in the existing built areas in Istanbul (pg. 181)

- The main objective is; to increase social awareness against disasters, to build disaster resilient and safe settlements and to minimize loss of life and property caused by disasters through risk mitigation practices (pg. 189)

- Disaster resilience of critical infrastructure facilities in Istanbul will be increased. It will be ensured that cultural and natural assets in Istanbul are resilient to disasters (pg. 190) (The Ministry of Development, 2019). 
However, as it's understood from the passages above, the content of the Eleventh Development Plan limitedly refers only disaster related resilience but there is not a particular reference, application or process explanation related to resilient urban development or urban resilience planning. Furthermore, the disaster resilience policies are basically for Istanbul, the biggest metropolitan city in Turkey, where there is an expected earthquake in the following years.

In the meanwhile, regional plans address the transformation of national priorities into local plans. The Ministry of Development is in charge of developing or delegating to make regional plans. Moreover, RDAs are responsible to prepare/delegate regional plans based on the Law of the Establishment of Regional Development Agencies (No. 5449). Nevertheless, regional plans are optional, so, the content of the regional plans are generally substituted by metropolitan land use plans. These plans should be prepared to regulate socio-economic development trends, adjust land use decisions development potential of settlements and sectorial objectives, as well as the distribution of activities and infrastructure, congruent with regional and national planning decisions (Ünsal and Türk, 2014; Yomralıoğlu and Ülger, 2014; Karakayacı, 2015; Ertugal, 2017). In this paper, 2014-2023 Istanbul Regional Development Plan was taken as a sample, since it's the most recent and still valid plan. The main targets of the plan include creating "globally decisive, high value-added, innovative and creative economy; fair sharing, inclusive and learning society and joyful, authentic urban spaces and sustainable environment". The plan has many other sub-targets explained as multi-dimensional strategies. However, there are no tools described to apply these strategies and there is not a focus on a detailed vulnerability assessment to show how these strategies will address them.

Furthermore, the macro scale physical plans in the planning hierarchy aim to put forward strategic and spatial planning decisions. Recently, based on the Law on Metropolitan Municipality (No. 5216), where metropolitan municipalities are responsible to prepare and approve metropolitan land use plans. The scale of the plan isn't mentioned in the Law on Land Development Planning and Control (No. 3194), conversely, in the Regulation of Spatial Planning (2014), the scale varies from 1/25.000, 1/50.000, $1 / 100.000$ to $1 / 200.000$. Metropolitan Land Use Plan of Istanbul (2009) was analyzed to represent this category of plans. This plan illustrates a comprehensive framework about the social, economic, ecologic, spatial and institutional vulnerabilities of the city as well as possible policies to address them with the appropriate tools. The plan presents a useful background for resilience analysis, however, it doesn't recognize the unexpected disturbances and it doesn't mention "urban resilience" as an important focus for the current turbulent environment.

In addition to these, the spatial plans aim to achieve sustainable urban form depending on The Article 1 of the Law on Land Development Planning and Control (No. 3194), which indicates to construct buildings and settlements in accordance with a plan, science, health and environmental conditions, constituting the backbone of spatial planning practices (Üstündağ and Şengün, 2011). However, it's obvious that the insufficiency of planning process which is mainly physical instead of being spatial intertwined with economic and social contents, brought about vulnerabilities in the cities. For the evaluation of this category of plans, 1/5000 and 1/1000 scale İstanbul Bağcılar Square Urban Regeneration Plans and İstanbul Beyoğlu Camiikebir District Special Project Area Plans were analyzed as samples. These plans were obtained from the website of the Ministry of Environment and Urbanism (Url-1; Url-2). It can be stated that these plans were prepared without taking into account the interdependencies between all the urban aspects and the impacts on the total urban area. Moreover, based on the content of the plan reports, it's possible to interpret that these plans offer short term solutions causing the problems to be accumulated in the long term and to become bottlenecks for urban development. 


\subsection{Interpreting the existing urban plans and planning scales through resilience concept}

Along with these appraisals, it's also crucial to assess if the national, regional and local level plans have background to address "urban resilience", so as to identify how urban resilience can be used to improve these arguments. This assessment can be done through the attributes of urban resilience, which can be grouped as "stability and capacity" related attributes and "dynamism" related attributes from institutional success perspective. These attributes are crucial to consider since the definition of resilience is rooted both in the regaining stability and adapting to new circumstances continuously. Just to figure out a general framework, it's possible to determine which criteria have to be met for "resilient stability, resilient response capacity and dynamism". In this sense, it's possible to check if the plans refer to the identification of a detailed vulnerability analysis and the description of unexpected disturbances that can be caused by the existing vulnerabilities. This can relate with "resilient stability" attribute. Reviving if the plans have policies/actions related to detailed risk management can give an account of "resilient response capacity" attribute. Finally, analyzing the plans on the basis of having policies to enhance governance capacity can contribute to assess them for matching "dynamism" attribute. Table 1 puts forward an evaluation about the content of the diverse scaled plans and their relation with urban resilience perspective.

Table 1. Evaluating the Urban Plans through Urban Resilience Perspective

\begin{tabular}{|c|c|c|c|c|}
\hline \multirow{2}{*}{$\begin{array}{l}\text { Planning } \\
\text { Scale }\end{array}$} & \multirow{2}{*}{ Plan Title } & \multicolumn{3}{|c|}{ Resilience Attributes } \\
\hline & & Resilient Stability & Resilient Response & Dynamism \\
\hline National & $\begin{array}{l}\text { Eleventh Development } \\
\text { Plan }\end{array}$ & $\begin{array}{l}\text { Analysis on the existing } \\
\text { situation on the pre-plan } \\
\text { period; } \\
\text { Lacking detailed } \\
\text { vulnerability analysis; } \\
\text { Lacking description of } \\
\text { unexpected disturbances }\end{array}$ & $\begin{array}{l}\text { Mentioning the need for the } \\
\text { preparation of inclusive } \\
\text { hazard and risk maps for } \\
\text { resilience strategy } \\
\text { development }\end{array}$ & $\begin{array}{l}\text { Aiming to assist institutions to act } \\
\text { more consistently and deliberately } \\
\text { in forward-looking decision making } \\
\text { process to determine, evaluate and } \\
\text { supervise hazard risks-uncertainty } \\
\text { emphasis }\end{array}$ \\
\hline Regional & $\begin{array}{l}\text { 2014-2023 Istanbul } \\
\text { Regional Development } \\
\text { Plan }\end{array}$ & $\begin{array}{l}\text { Lacking detailed } \\
\text { vulnerability analysis; } \\
\text { Lacking description of } \\
\text { unexpected disturbances }\end{array}$ & $\begin{array}{l}\text { Strategies to enable disaster } \\
\text { management system }\end{array}$ & $\begin{array}{l}\text { Aiming to improve existing } \\
\text { cooperation and establishing new } \\
\text { partnerships, providing fast and } \\
\text { secure access to high-quality } \\
\text { information }\end{array}$ \\
\hline $\begin{array}{l}\text { Macro Scale } \\
\text { Physical }\end{array}$ & $\begin{array}{l}\text { Metropolitan Land Use } \\
\text { Plan of Istanbul (2009) }\end{array}$ & $\begin{array}{l}\text { Detailed vulnerability } \\
\text { assessment; } \\
\text { Lacking description of } \\
\text { unexpected disturbances }\end{array}$ & $\begin{array}{l}\text { Mentioning the preparation } \\
\text { of emergency action plans } \\
\text { for various hazard risks } \\
\text { Lacking description of } \\
\text { possible actions in the face } \\
\text { of unexpected threats of any } \\
\text { kind }\end{array}$ & $\begin{array}{l}\text { Aiming to determine the required } \\
\text { institutional capacity, developing the } \\
\text { monitoring and assessing } \\
\text { mechanism }\end{array}$ \\
\hline Local & $\begin{array}{l}\text { Land Use Plans and } \\
\text { Detailed Local Plans for } \\
\text { Bağcilar and Beyoğlu } \\
\text { Municipalities }\end{array}$ & $\begin{array}{l}\text { SWOT analysis- Lacking } \\
\text { description of unexpected } \\
\text { disturbances }\end{array}$ & $\begin{array}{l}\text { No policies/actions related to } \\
\text { risk management }\end{array}$ & $\begin{array}{l}\text { No reference to enhancing } \\
\text { governance capacity }\end{array}$ \\
\hline
\end{tabular}

As it's seen from Table 1, national scaled development plan and macro scale metropolitan land use plan can serve as a basis for the formulation and integration of urban resilience based plans; however, with an advancement. In a wider perspective, urban resilience plans can be defined as comprehensive plans which describe the general outline for what to address and where to start, and then put the wide-ranging policies and capacity attributes to be followed. The actions, an urban resilience based plan suggests, specify a major precaution in reducing harm to people, property, and other resources before and after unexpected disturbances. It aims to reduce risks and vulnerability at macro or local level. For this reason, spatial plans can contribute to all aspects of urban resilience plans linked to physical urban structure. Obviously, urban resilience plans not only promotes spatial planning, organization of land use and incompatibilities in land use, but also it becomes a comprehensive and complementary approach by attaching importance to information sharing, encouraging self-organization and increasing the capacity of communities to adapt. This can add a macro scale perspective to urban resilience plans. 
Considering the planning scale, the overall target should have a nationwide perspective as well as regional and local level connectedness. In order to construct such a comprehensive and detailed framework to change the contemporary urban planning approach into a transformable and adaptive model, the multi-scale perspective is surely desired. Macro scale is appropriate to point out the general targets about spatial, economic, social or environmental development; such as determining the appropriate land use according to the frequency and intensity of the existing risks, having diverse economic growth policies or maintaining socio-cultural development. On the other hand, the spatial vulnerabilities of a neighborhood can be basically overcome through detailed local plans. Moreover, local scale can also be more congruent considering the spatial conditions requiring advanced attention such as areas susceptible to natural hazards; areas where the effects of hazardous events need to be mitigated and areas where resilient response is needed to be improved (escape routes and collection points). At this point, an important question can be raised which realizes the identification of "to what" resilience has to be developed. Five elements process starts with the clarification of the main vulnerabilities. So, in order to clarify the key vulnerabilities, definitely there has to be a multi-scale approach. However, considering the unexpected changes, it's important to start with the local scale, since local management can be more aware of the vulnerabilities and the basic needs of the community. Additionally, it can be easier to organize public participation.

\subsection{Defining the context of urban resilience plans}

The urban resilience plans can basically refer to short term strategies such as 1 to 5 years and 5 to 10 years period, because of the unexpectedly changing global dynamics. If the long term period is considered from 10 to 20 or 20 to 50 years, it can be difficult to adapt to and transform based on the changing circumstances. Another possible understanding can be developed such as a new interpretation of short term period which is 1 to 5 years and long term period from 6 to 10 years. So, emergency situations can be planned for a shorter term, and the strategies for capacity building or economic development can be planned for longer term with a monitoring system, supporting an ongoing feedback. The planning periods have to be determined in the Law on Land Development Planning and Control (No. 3194) and the Regulation of Spatial Planning for each type of plan. Figure 3 presents a proposed urban planning hierarchy in basic terms, including urban resilience plans.

Considering the national scale, a new strategic plan called "Five Years National Strategy for Urban Resilience" can be proposed. In the meanwhile, development plans and regional plans can include chapters where the resilience based development strategies and actions are analyzed. "Five Years National Strategy for Urban Resilience" can present; the national vulnerability assessments; how promote capacity against unexpected disturbances and the monitoring of the governance success to manage change. Moreover, it can define the overall resilience based economic, social, ecologic and spatial development strategies and it can function as a macro level risk mitigation plan from resilience perspective. This plan can be prepared under the coordination of Ministry of Development and Ministry Environment and Urbanism collaborating with the participants from other Ministries, Metropolitan and District Municipalities, representatives of NGOs and experts from the Universities.

For the macro scale physical plans, Metropolitan Land Use Plans can be upgraded with urban resilience perspective such as "Urban Resilience Strategy and Land Use Plans". Therefore, they can comprehend all the targets of the metropolitan land use plans and additionally, they can act like a bridge among all other macro scale urban plans and serve as a broad guideline and a check list for the maintenance of sustainable urban development both in strategies and spatial implementations. These plans can be prepared by metropolitan 
municipalities in collaboration with district municipalities, representatives of NGOs and experts from the Universities, in accordance with other upper-level plans.

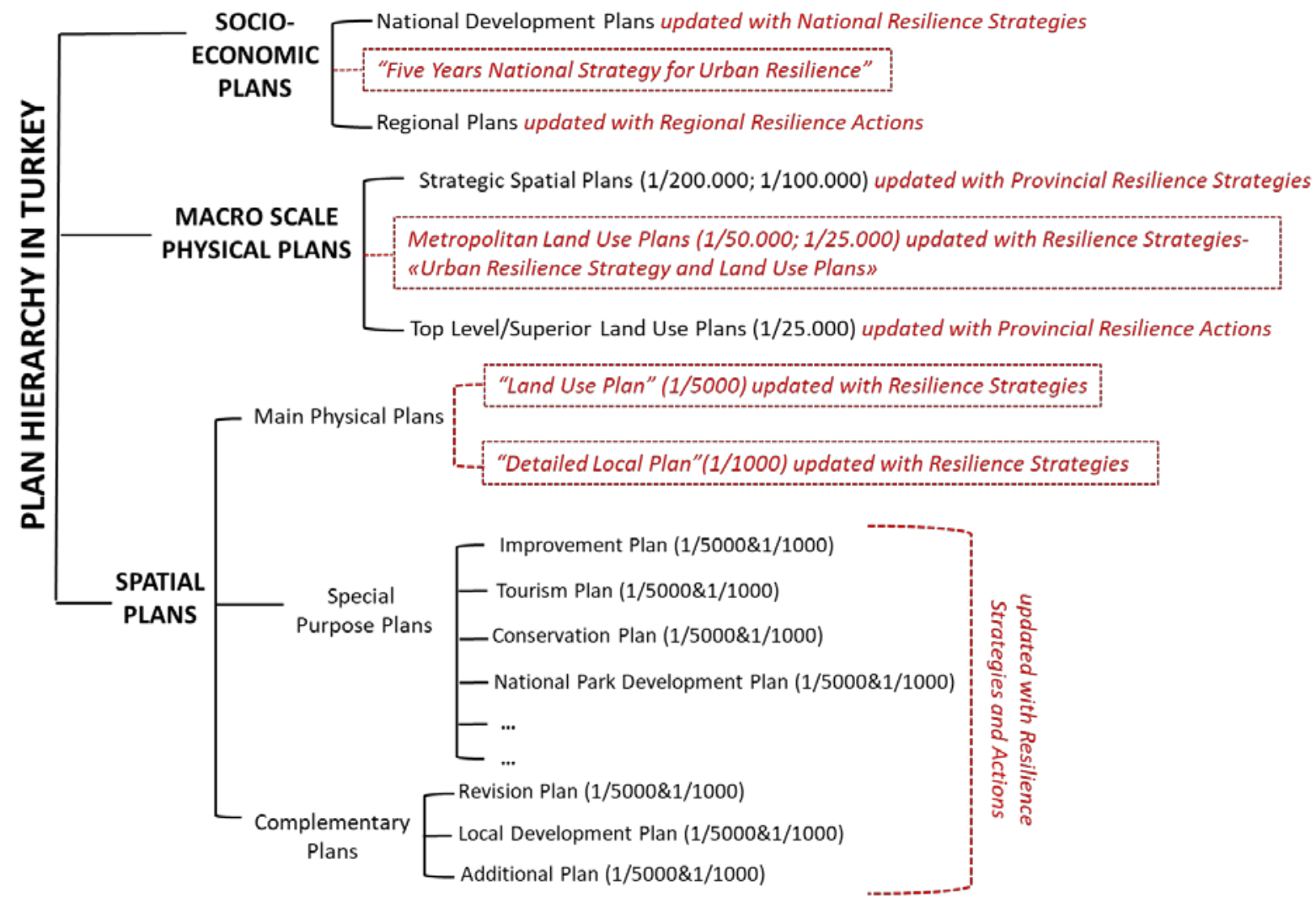

Figure 3. Proposed Urban Planning Hierarchy

Finally, all physical plans can be updated with resilience perspective and should follow intrascales policies. They can be updated through an "urban resilience planning process" and represent the spatial decisions taken in the "Urban Resilience Strategy and Land Use Plans". Additionally, all different purpose and different scale urban plans should have the aim of maintaining urban resilience to support sustainable urban development. The important issue of this suggested framework is that it has the logic of a basic urban planning process but at the same time, it comprehends essential components with an updated interpretation. Primarily, it should be based on the mentioned three complementary aspects; "Resilience to what", "Where" and "How". In general terms, these plans can be prepared by the coordination of metropolitan and district municipalities as well as Special Provincial Administration, in collaboration with the representatives of NGOs, experts from the universities and citizens.

All stakeholders who have the authority to prepare the urban resilience plans should work collaboratively with the regulatory bodies to create the regulations and the amendments in existing laws in order to enhance urban resilience. With this regard, urban resilience plans have to be described in the Regulation of Spatial Planning, Law on Land Development Planning and Control (No. 3194), Law on Special Provincial Administration (5302) and Law of Urban Regeneration (Transformation) in Areas under Disaster Risk (No. 6306). It's compulsory because urban resilience planning offers a new management systemsemphasizing the roles of the planning stakeholders- and an updated urban planning process framework which requires the coherence with the national, regional or local development plans. Considering the existing hierarchy among the urban plans and the responsible 
administrations for planning, urban resilience planning has to be acknowledged in the urban planning system. At this point, following section describe the resilience based updates for the existing legislative system.

\section{Defining Urban Resilience Planning in the Existing Legislative System in Turkey}

\subsection{Evaluation of the current legislative system}

The aim to define resilience in the legal system requires achieving the gaps in the urban planning legislative system and governance capacity insufficiencies. To start the overall assessment, the laws and regulations describing the urban plan types and the related authorities for making urban plans have been analyzed. These legislative tools can be listed as follows;

-Law on Land Development Planning (No. 3194),

-Law on Special Provincial Administration (No. 5302),

-Law of Urban Regeneration (Transformation) in Areas under Disaster Risk (No. 6306),

-Law of Mass Housing (No. 2985),

-Law on Metropolitan Municipalities (No. 5216),

-Municipal Law (No. 5393) and,

-Regulation of Spatial Planning.

The reason to include the Law of Mass Housing (No. 2985) and the Law of Urban Regeneration (Transformation) in Areas under Disaster Risk (No. 6306) in this list is the fact that these tools involve the authority of national level stakeholders (Ministry of Environment and Urbanism and Housing Development Administration of Turkey [TOKi]). Considering the Law of Mass Housing (No. 2985), Article 4 (Amendment: 5/5/2004 -5162/2 Art.) (Amended first paragraph: 24/7/2008-5793/7 Art.) express that, TOKI has been authorized to make, delegate or revise every kind of plans at any scale within squatter regeneration areas, TOKI owned lands or new housing development areas identified by the Province. In addition to this, TOKI can develop squatter regeneration projects, construction works and financial arrangements based on Article 8 (Supplementary: 5/5/2004 - 5162/4 Art.) and it can also develop regeneration projects based on Article 8 (Amended paragraph: 24/7/2008-5793/10 Art.). Therefore, it can be stated that, after 2000s, TOKI gained extensive authority in spatial planning and construction activities.

Furthermore, the Law of Urban Regeneration (Transformation) in Areas under Disaster Risk (No. 6306) aims to set principles and procedures regarding improvement, evacuation and renewal of areas (lands and plots with risky structures) under disaster risk. Article 2 defines risky areas and risky structures. Article- 6 (Amendment 14/4/2016-6704/23 Art.) explains that the Law authorizes the Ministry of Environment and Urbanism for the identification of "areas and structures under risk" and "improvement", "evacuation" and "renewal" of all the nationwide structures being under risk. Accordingly, this law empowers Ministry of Environment and Urbanism.

On the other hand, Regulation of Spatial Planning which entered into force by its publication in the Official Gazette on 14 June 2014 is one of the most crucial tools which sets the principles and procedures for the construction and implementation of spatial plans. The new regulation in 2014 introduced significant changes by means of the definition of spatial strategic plans which has to be adopted nationwide in place of regional plans. This regulation also promoted Ministry of Environment and Urbanism.

Additionally, The Article 6 of the Law on Land Development Planning (No. 3194) puts forward the basic plans within a category of "Regional Plans" and "Land Development Plans". As expressed in Article 8, Ministry of Development (State Planning Organization since 2011) 
was legitimated to make or delegate regional plans and relevant municipalities were pointed out to make or delegate land development plans. In the meanwhile, Article 9 expresses that Ministry of Environment and Urbanism is authorized to make, delegate, amend and approve partially or completely, land development plans and amendments in certain conditions related to infrastructure, transmission lines and disasters affecting public life or mass housing. Moreover, Article 9 (Supplementary: 24/11/1994 - 4046/41 Art.) mentions Privatization Administration to approve land development plan amendments, localized development plans and appropriate development planning status of the land and parcels within municipal boundaries and adjacent areas owned by entities included in the privatization program.

Besides, in terms of making metropolitan/provincial level spatial plans, Law on Special Provincial Administration (No. 5302) expresses broad duties of the Special Provincial Administrations in Article 6. They have services of local and common nature. Moreover, Article 6-b identifies the "services that are related to land development planning and control (...)". While, Law on Metropolitan Municipalities (No. 5216) empowers metropolitan municipalities "to prepare or demand to prepare, approve and implement master plans of every scale between $1 / 5.000$ and 1/25.000 (...)" (in Article 7).

For local scale implementations, the Municipal Law (No. 5393) provides the legal basis. In terms of local service provision, Article 14 of the Municipal Law (No. 5393) promises for supporting accessibility to reach facilities as explained "The municipal services shall be rendered in the most appropriate manner at the places nearest to the citizens." Moreover, Article 41 suggest to create strategic plans, Article 53 proposes "plans according to the characteristics of the territory in order to prevent fire, industrial accidents, earthquake and other natural disasters and to minimize the risks of such events and prepare the teams and equipment for action" and Article 73 is well known with its reference to "urbanization and development projects in order to reconstruct and restore the ruined parts of the city; to create housing areas, industrial and commercial zones, technology parks and social facilities; to take measures against the earthquake risk or to protect the historical and cultural structures of the city".

After the revision of these laws, it has to be remarked that, there is the dominance of central authorities then the local authorities mentioned in the legislative system. Table 2 indicates that there is a vast diversity of stakeholders having the authority to make different types of plans in various scales which causes disorganization and conflicts. As mentioned before, having many stakeholders with different roles seems as an advantage. However, without coordination and cooperation, it may only create conflicts. 
Table 2. Existing Urban Planning Actors, Legal Tools and the Planning Scale (Adapted from ISTKA, 2011)

\begin{tabular}{|c|c|c|}
\hline Competent Authority & LawNo. and Title & Jurisdiction \\
\hline $\begin{array}{l}\text { Ministry of Development, Ministry of Environment and } \\
\text { Urbanism }\end{array}$ & Law on Land DevelopmentPlanning 3194 & Regions \\
\hline Regional DevelopmentAgency (RDA) & EstablishmentLaw of RDAs 5449 & Regions \\
\hline Ministry of Environment and Urbanism & $\begin{array}{l}\text { Law of Urban Regeneration (Transformation) in Areas under } \\
\text { Disaster Risk (No.6306) }\end{array}$ & Provincial, municipal borders, metropolitan municipalities \\
\hline Ministry of Food, Agriculture and Livestock & Land and Soil Conservation Law 5403 & Provincial, municipal borders, metropolitan municipalities \\
\hline Governorship or Metropolitan Municipalities & Law on Special Provincial Administration 5302 & Provincial, municipal borders, metropolitan municipalities with provindial boundaries \\
\hline Metropolitan Municipalities & The Law on Metropolitan Municipalties 5216 & Metropolitan municipality boundaries \\
\hline \multirow{2}{*}{$\begin{array}{l}\text { Ministry of Environment and Urbanism, Municipalities and } \\
\text { Governorship }\end{array}$} & Law on Land Development Planning 3194 & $\begin{array}{l}\text { Within and outside the boundaries of the municipality and the municipal adjacent } \\
\text { area }\end{array}$ \\
\hline & Gecekondu Law 775 & Gecekondu Prevention Zone \\
\hline Municipalties & Municipal Law 5393 & Within the boundaries of municipality and municipal adjacent area \\
\hline Governorship & Village Law 442/3367 & Villages \\
\hline $\begin{array}{l}\text { Ministry of Environment and Urbanism, Ministry of Culture } \\
\text { and Tourism }\end{array}$ & Law on Tourism Encouragement 2634 & Tourism Regions and centers \\
\hline $\begin{array}{l}\text { Ministry of Environment and Urbanism, Ministry of } \\
\text { Environment and Forests }\end{array}$ & National Parks Law 2873 & National Parks \\
\hline Ministry of Forestry and Water Affairs & $\begin{array}{l}\text { Law on the Organization and Duties of the Ministry of } \\
\text { Environment and Forests } 4856\end{array}$ & Forests \\
\hline Supreme Board of Planning Coordination for Bosphorus & Bosphorus Law 2960 & Bosphorus Area \\
\hline Special EnvironmentalProtection Agency & $\begin{array}{l}\text { Statutory Decree No. } 383 \text { on Establishment of Special } \\
\text { Environmental Protection Agency Presidency }\end{array}$ & Special Environmental Protection Region \\
\hline $\begin{array}{l}\text { Ministry of Environment and Urbanism, Municipalities and } \\
\text { Governorship, Ministry of Culture and Tourism }\end{array}$ & $\begin{array}{l}\text { Shore Law } 3621 / 3830 \\
\text { LawNo. } 2634\end{array}$ & $\begin{array}{l}\text { Coasts and Coastlines, } \\
\text { Land Acquired with Filling or Drying, Tourism Centers, Cultural and Tourism } \\
\text { Conservation and Development Zones }\end{array}$ \\
\hline Privatization Administration & Law No: 3194 Amending the Law No. 4046 & Land or plot acquired for the privatization program \\
\hline \multirow{2}{*}{ Ministry of Science, Industry and Technology } & Organized Industrial Zone Law 4562 & Organized Industrial Zones \\
\hline & $\begin{array}{l}\text { Industrial Zones Law } \\
\text { Technology Development Zones Law } 4691\end{array}$ & $\begin{array}{l}\text { Industrial Zones } \\
\text { Technology DevelopmentZones }\end{array}$ \\
\hline Ministry of Culture and Tourism & Law No. 2634 Amended by Law No. 4957 & Cultural and Tourism Conservation and DevelopmentZones, Tourism centers \\
\hline Housing Development Administration & $\begin{array}{l}\text { The Law of Mass Housing No. } 2985 \text { amended by Law No. } \\
5793\end{array}$ & $\begin{array}{l}\text { Gecekondu ConversionProject Application Areas, Plots and Land which are OWn } \\
\text { Property, The areas designated as Public Housing by Governorship }\end{array}$ \\
\hline Turkish State Railways & Law No. 5335 Amended by Law No. 5793 & Public Land which is own property subject to be Sold and Appraisal \\
\hline
\end{tabular}

\subsection{Interpretation of the stakeholders for urban resilience planning}

Obviously, one of the most significant additions of the urban resilience planning process is the provision of a collaborative decision of a wide range of urban planning authorities. It's essential to underline that one of the most important condition for resilience to work is the broad participation just as public organizations, private actors, associations, inhabitants and academicians. For this reason, the urban resilience planning process should firstly aim to clarify the urban planning stakeholders. This qualifies the "experts" (urban planning professionals) to identify the stakeholders for each scale of planning. Then, integrating the public into the urban planning process not only strengthens the consensus building on the most essential vulnerabilities, but also it supports the continual networking and eventually collective participation. Nevertheless, urban resilience planning process emphasizes the fact that, role sharing between actors has to be improved and this would enable the urban planning capacity to progress by the effective participation and qualify the urban planning process as well.

Considering the national and regional plans, the national level actors surely should be more active to exhibit the macro level development strategies. However, in view of local level development or implementation plans, the leading actor should be a local administration. It's clear that, local concerns such as unemployment, crime, housing affordability or education may be observed as minor problems (Cutter et al. 2008); however, they are the key vulnerabilities which trigger the impacts of disturbances. Therefore, ignoring the local authorities definitely causes more loses in the face of unexpected disturbances. For this reason, local governments should take decisions about sustainable land use and urban development. It's obvious that, resilience contributes urban planning through this desired decentralization and the increase in the strategic capabilities of the stakeholders. Accordingly, in order to avoid this conflictual organization, an ideal model of actor-mapping was developed based on the basic roles and the tools (Table 3). 
Table 3. Proposed Resilience Based Planning Stakeholders, Their Roles and Tools

\begin{tabular}{|c|c|c|c|}
\hline Roles & Scale & Stakeholders & Tools \\
\hline \multirow{7}{*}{$\begin{array}{l}\text { Control/ } \\
\text { regulation }\end{array}$} & \multirow{4}{*}{ Macro level (national/regional) } & Council of Ministers & $\begin{array}{l}\text { Legal } \\
\text { Financial }\end{array}$ \\
\hline & & Ministry of Environment and Urbanism & \multirow{2}{*}{$\begin{array}{l}\text { Legal } \\
\text { Financial } \\
\text { Technical Infrastructure }\end{array}$} \\
\hline & & Ministry of Development & \\
\hline & & Governorship & $\begin{array}{l}\text { Legal } \\
\text { Financial }\end{array}$ \\
\hline & Both macro and local level & $\begin{array}{l}\text { Public Units (Administrative Units of Prime Ministry } \\
\text { such as Presidency of Spatial Environment Agency, } \\
\text { TOKI or General Directorate of State Hydraulic } \\
\text { Works, State Railways) }\end{array}$ & \multirow[t]{3}{*}{$\begin{array}{l}\text { Knowledge } \\
\text { Technical Infrastructure } \\
\text { Financial }\end{array}$} \\
\hline & \multirow{2}{*}{$\begin{array}{l}\text { Local level } \\
\text { (provincial/municipal/neighborhood) }\end{array}$} & Metropolitan Municipalities & \\
\hline & & District Municipalities & \\
\hline \multirow{11}{*}{$\begin{array}{l}\text { Strategy } \\
\text { development }\end{array}$} & \multirow{4}{*}{$\begin{array}{l}\text { Macro level (national/ } \\
\text { regional) }\end{array}$} & Council of Ministers & $\begin{array}{l}\text { Legal } \\
\text { Financial } \\
\text { Knowledge }\end{array}$ \\
\hline & & Ministry of Environment and Urbanism & Knowledge \\
\hline & & Ministry of Development & Technical Infrastructure \\
\hline & & Governorship & $\begin{array}{l}\text { Financial } \\
\text { Knowledge }\end{array}$ \\
\hline & \multirow{4}{*}{ Both macro and local level } & General Directorate of Bank of Provinces & \multirow{5}{*}{$\begin{array}{l}\text { Knowledge } \\
\text { Technical Infrastructure }\end{array}$} \\
\hline & & Regional Development Agencies & \\
\hline & & Universities & \\
\hline & & Public Units & \\
\hline & \multirow{3}{*}{$\begin{array}{l}\text { Local level } \\
\text { (provincial/municipal/neighborhood) }\end{array}$} & Local NGOs & \\
\hline & & Metropolitan Municipalities & \multirow{2}{*}{$\begin{array}{l}\text { Knowledge } \\
\text { Technical Infrastructure } \\
\text { Financial }\end{array}$} \\
\hline & & District Municipalities & \\
\hline \multirow{6}{*}{$\begin{array}{l}\text { Infrastructure } \\
\text { development }\end{array}$} & Macro level (national/regional) & Ministries & $\begin{array}{l}\text { Legal } \\
\text { Financial } \\
\text { Technical Infrastructure }\end{array}$ \\
\hline & \multirow{3}{*}{ Both macro and local level } & Public Units & \multirow{3}{*}{ Knowledge } \\
\hline & & Governorship & \\
\hline & & Regional Development Agencies & \\
\hline & \multirow{2}{*}{$\begin{array}{l}\text { Local level } \\
\text { (provincial/municipal/neighborhood) }\end{array}$} & Metropolitan Municipalities & \multirow{2}{*}{$\begin{array}{l}\text { Financial } \\
\text { Technical Infrastructure } \\
\text { Knowledge }\end{array}$} \\
\hline & & District Municipalities & \\
\hline \multirow{8}{*}{ Innovation } & \multirow[b]{2}{*}{ Macro level (national/regional) } & Council of Ministers & $\begin{array}{l}\text { Legal } \\
\text { Financial }\end{array}$ \\
\hline & & Ministries & $\begin{array}{l}\text { Financial } \\
\text { Technical Infrastructure } \\
\text { Knowledge }\end{array}$ \\
\hline & \multirow{4}{*}{ Both macro and local level } & Administrative Units & $\begin{array}{l}\text { Financial } \\
\text { Knowledge }\end{array}$ \\
\hline & & Universities & \multirow{3}{*}{ Knowledge } \\
\hline & & Chambers & \\
\hline & & NGOs & \\
\hline & \multirow{2}{*}{$\begin{array}{l}\text { Local level } \\
\text { (provincial/municipal/neighborhood) }\end{array}$} & Metropolitan Municipalities & Technical Infrastructure \\
\hline & & District Municipalities & $\begin{array}{l}\text { Knowledge } \\
\text { Financial }\end{array}$ \\
\hline & Macro level (national/regional) & Ministries & $\begin{array}{l}\text { Legal } \\
\text { Financial }\end{array}$ \\
\hline & & Administrative Units & Financial \\
\hline Collaboration & Both macro and local level & Governorship & Knowledge \\
\hline Comadratom & Doum macro and local level & Universities & \\
\hline & & Chambers and NGOs & Knowledge \\
\hline & Local level & Metropolitan Municipalities & Knowledge \\
\hline & (provincial/municipal/neighborhood) & District Municipalities & Financial \\
\hline & Macro level (national/regional) & Ministries & $\begin{array}{l}\text { Legal } \\
\text { Financial }\end{array}$ \\
\hline & Mracro lever (national/Iegional) & General Directorate of Bank of Provinces & $\begin{array}{l}\text { Knowledge } \\
\text { Financial }\end{array}$ \\
\hline & & Administrative Units & \\
\hline & & Governorship & \\
\hline Participation/ & Both macro and local level & Regional Development Agencies & Knouledap \\
\hline networking & Doun macro and local level & Universities & Nnowiedge \\
\hline & & Chambers & \\
\hline & & NGOs & \\
\hline & & Metropolitan Municipalities & Legal \\
\hline & $\begin{array}{l}\text { Local level } \\
\text { (provincial/municipal/neighborhood) }\end{array}$ & District Municipalities & $\begin{array}{l}\text { Knowledge } \\
\text { Financial }\end{array}$ \\
\hline & & Citizens & Knowledge \\
\hline
\end{tabular}


The planning tools were categorized as legal, financial, technical infrastructure and knowledge and were identified for each specific role of the stakeholders. Legal tools can be represented such as development of evaluation and monitoring methods through laws or regulations. Financial tools can be characterized such Public Private Partnership model, public investments, public funds, private sector investments, EU funding sources and other international funds. Technical infrastructure tools can be signified such as hazard mitigation policies/plans, regional plans, development plans more in the macro scale and master/strategic plans as well as local development plans/projects more in the local scale. Moreover, strategies against any kind of internal and external disturbances and control of the service provision can be interpreted both in macro and local level. Finally, knowledge tools can be listed such as social, economic or institutional networks, innovation strategies and creativity both in macro and local level.

The other component of this framework is the roles of the actors which were classified as;

- Control/regulation (defining the legal and institutional structure of the plan, approving the plan),

- Strategy development (making plans, scheduling of scenarios, prioritization of priority issues, determination of long and short term targets. This role is parallel with innovation),

- Infrastructure development (database creation, identifying which data needs to be produced/updated, identification of monitoring systems),

- Collaboration (mobilizing consensus, making task distributions, making feedback of changing decisions and objectives, preparation of work schedules),

- Participation/networking (identification of potential stakeholder groups),

- Innovation (development and implementation of innovative approaches).

"Strategy development" is the main role which proposes to make urban plans of different scales, as well as to schedule scenarios and to determine long and short term targets. From this perspective, urban resilience planning process can be shaped with the responsible actors of strategy development. "Control/regulation" is the role, which uses the legal tool. It also makes law, regulations and approves the plans. Therefore, this role is fundamental to articulate urban resilience planning to the legal system. In the meanwhile, "infrastructure development" promotes data creation and identification of the lacking data in order to achieve the analysis for strategy development. At this point a crucial point to emphasize the production of municipal data to make comprehensive systems analysis. If there is lack of data, then this causes bottlenecks to find out the real cause of problems and establish resilience principles to avoid them or establish the unwanted consequences in the local scale. Therefore, in order to solve this problem about data production, institutions of municipalities which can produce data have to be supported legally or financially. In addition to these, mobilizing consensus and making task distribution among stakeholders are the responsibilities of "collaboration", which then leads to "participation/networking" to identify the potential stakeholder groups and provide participation.

Table 3 proposes a sample of a comprehensive expansion of the offered actor-mapping framework from national to neighborhood scale with a broader point of view. Definitely, all of the stakeholders are responsible in terms of their professional field such as environment, transportation, communication, energy and natural resources, forestry, economy, development and so on. For each role, surely there is a leading actor who has more resources, background or power. For instance, in terms of supporting innovation or providing technical infrastructure, the leading macro level actor can easily be the Ministry of Science, 
Industry and Technology. With this respect, what is crucial here is the definition of "Urban Resilience Coordination Units" among macro level and local level management, for the accomplishment of each specific role. To establish those coordination units in each level of management necessitates a renovation/ reorganization process. Moreover, collaboration and participation/networking roles have to be the key at this point. These units aim to develop effective multi-agency responses and consulting across macro and local level actors to build conflict-resolution mechanisms to ensure compliance. They can have sub-units according to the role they have such as strategy development coordination unit, innovation coordination unit and so on. Moreover, there is a necessity to establish an inclusive coordination among all these units for a sustainable and resilient development process. This can be carried out with "Urban Resilience Coordination Department" which have an administrative identity and settled in the metropolitan level in order to control the applications better.

Consequently, these units typically should have representatives from all stakeholder groups from all different scales. These representatives can be selected among urban planners who are eligible for running an urban planning process. Besides, NGOs and local governments can establish a community network collaboratively, which provides diverse information flows such as various informative publications, educative programs, group meetings and so on. At this point, Public Opinion Surveys also help neighborhoods and households to be a part of the process. Indeed, academicians should always be the part of this unit. This kind of role distribution and coordination among all the actors promote awareness-raising for the participation in terms of service provision, infrastructure development and sustainable urban growth. It strengthens obtaining consents, core responsibilities for undertaking development, project management accountabilities and ongoing management arrangements. Moreover, the decisions can be implemented quickly, depending on the definitive sharing of the application tools, especially clear funding provisions.

As an example from Istanbul, the only similar approach of such coordination units can be the Istanbul Metropolitan Planning and Design Centre (IMPDC), which was established in 2005 to strengthen the coordination between the various departments of the IMM to help progress the city's master plan. IMPDC has a public-private partnership funding and it works as an associate firm of IMM. There are 400 experts, academics, and main municipal members working in this center. Metropolitan Land Use Plan (2009) was prepared by this center. Even though, IMPDC is directed by many experts, populist politics captured the decision-making and projects were partially implemented, as a result of the lack of administrative encouragement (Uzun, 2010).

Besides these coordination units, the real contribution is the establishment of the administration unit which is in charge of the application of urban resilience planning-so called five elements process. This unit can be the "Council of Urban Resilience Planning" with a national status and it can work collaboratively with the coordination units. For urban resilience planning process of each scale, Council of Urban Resilience Planning can contact the experts and initiate the process. Moreover, during the Policy Delphi Survey and Public Opinion Survey Processes, the council and the coordination units can manage the effective networking among the stakeholders. Consequently, Figure 4 illustrates the proposed urban planning stakeholders in red color. 


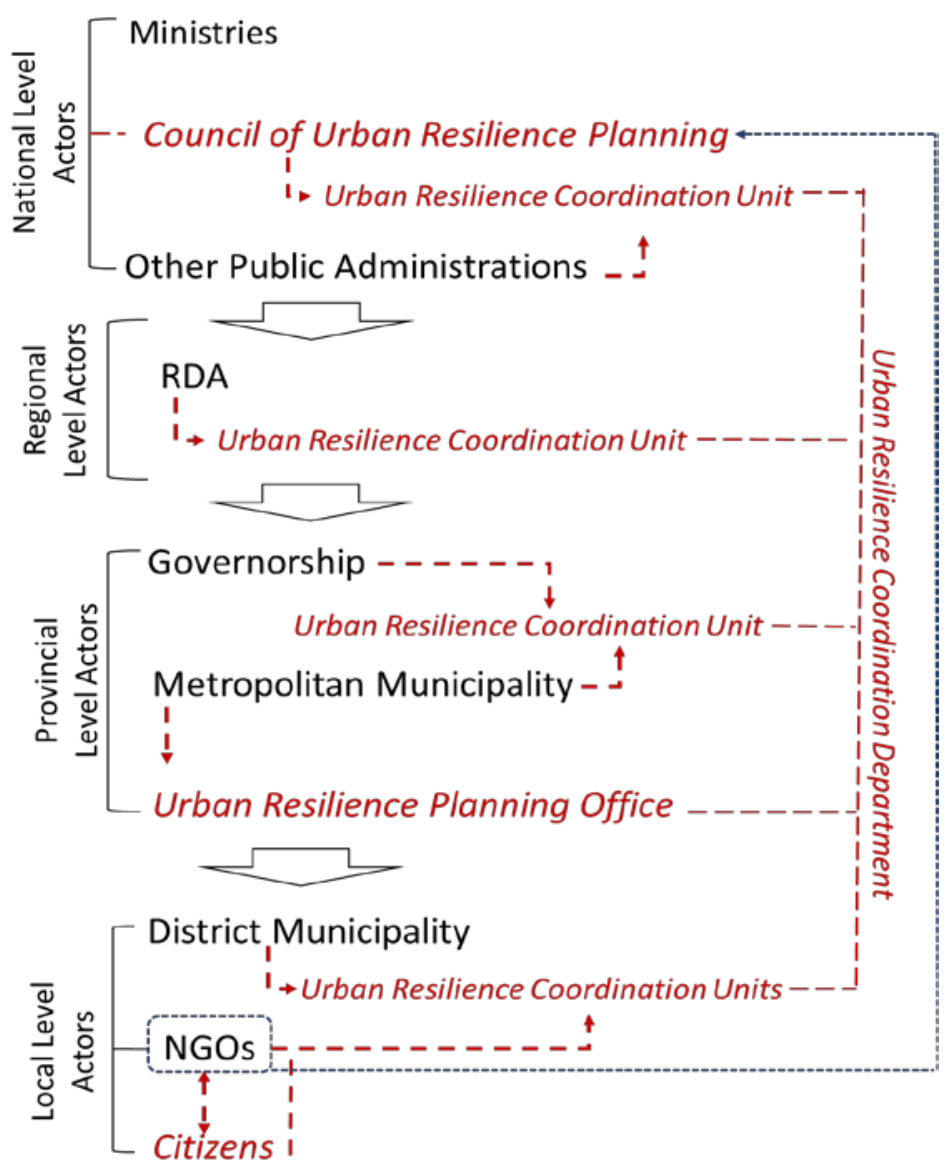

Figure 4. Proposed Stakeholders of Urban Resilience Planning

\subsection{Interpretation of the legal framework for urban resilience planning}

As a result of these assessments, an important outcome has to be the evaluation of the laws in terms of their consistency with the proposed management scheme. This conclusion is congruent to obtain the "governance capacity enhancement and success" through the legal tools. Primarily, as it's determined in Table 4, the laws don't include any Article about how to promote "innovation". Besides, most of them mention "collaboration" merely to explain the collaborative share of duties, powers and responsibilities within the same administrative unit. Only the Municipal Law (No. 5393) mentions launching collaboration among diverse stakeholders particularly for emergency planning. This can be interpreted as a strength for urban resilience planning process, since it aims to create a multi-centered organization of governance. It's almost the same for "participation/networking".

Aiming to improve public awareness through media is the only attempt that was described in the Law of Urban Regeneration (Transformation) in Areas under Disaster Risk (No. 6306). This law was supposed to be the most relevant legal tool for developing disaster-resilience based urban policies; however, it lacks to define the criteria to accomplish governance capacity. "Strategy development" comes down to the identification of the roles of the public units to make plans and the superficial content of the plans. Regulation of Spatial Planning is the only legal tool which explains all the plan types more in details. Additionally, the Municipal Law (No. 5393) mentions the "strategic plan and performance plan" concepts, which can contribute to the formation of "Urban Resilience Strategy and Land Use Plans".

Finally, in the laws, "control/regulation" is inferred as the authorization of plan approval. Most of the time strategy development and control/regulation intertwine. Under these 
circumstances, some recommendations were projected in Table 5. First of all, as the most significant law among all directing urban development, Amendments were suggested for the Law on Land Development Planning and Control (No. 3194) with the aim of integrating "urban resilience plans" in the legislative system and generating a participatory management. The following list summarizes the prominent proposals for the other laws;

- Regulation of Spatial Planning- enhancement of the regulation in order to accompany the application of the Law on Land Development Planning (No. 3194),

- The Law of Urban Regeneration (Transformation) in Areas under Disaster Risk (No. 6306) - upgrading to include both natural, man-made and social risks, therefore it functions as a base for risk mitigation analysis.

- Law on Special Provincial Administration (No. 5302) - defining the resilience coordination units in the provincial level and their interactions with the national and local level as the most crucial addition.

- Law of Mass Housing (No.2985)- specializing on the production of social housing instead of an extensive authority to make plans and including other stakeholders in the production of social housing projects.

- Municipal Law (No. 5393)-improving Article 15 about the powers and privileges of municipalities so that it can provide coherence with "Urban Resilience Strategy and Land Use Plan" while making plans. Also with an amendment in the Article 24, that mentions the specialist commissions, urban resilience planning coordination unit and its working the principles can be defined. Finally, considering the urban regeneration and development areas, Article 73 can be enhanced in order to comprehend the "Urban Resilience Coordination Department" and "Urban Resilience Coordination Units" in terms of emergency planning.

- Law on Metropolitan Municipalities (No. 5216) - reorganizing to include urban resilience planning process to supervise land development planning and control. Article 11 and 15 can be restructured to include the authorization of Metropolitan municipalities to make and approve "Urban Resilience Strategy and Land Use Plan" defining the "Urban Resilience Coordination Department" and "Urban Resilience Coordination Units". 


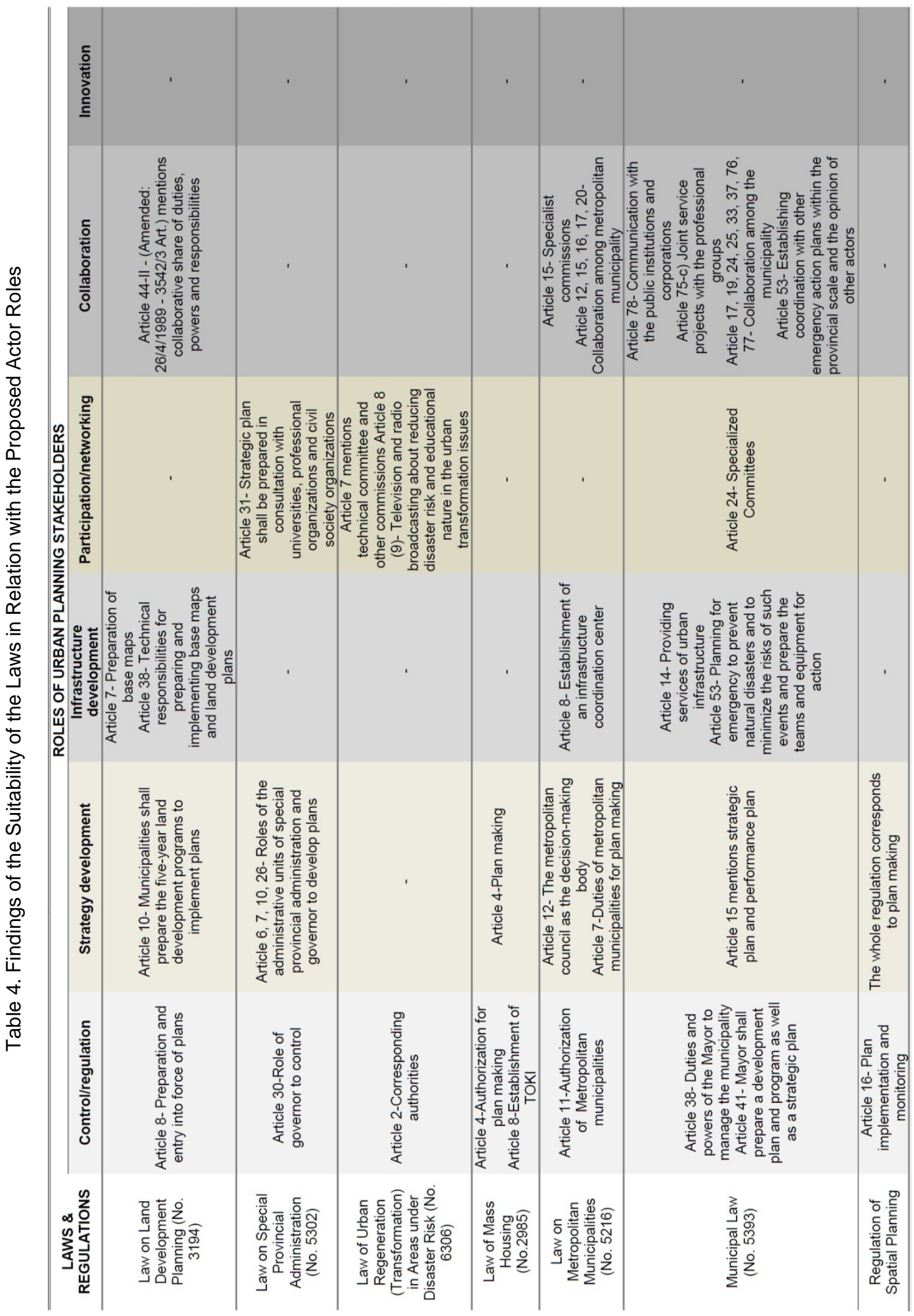




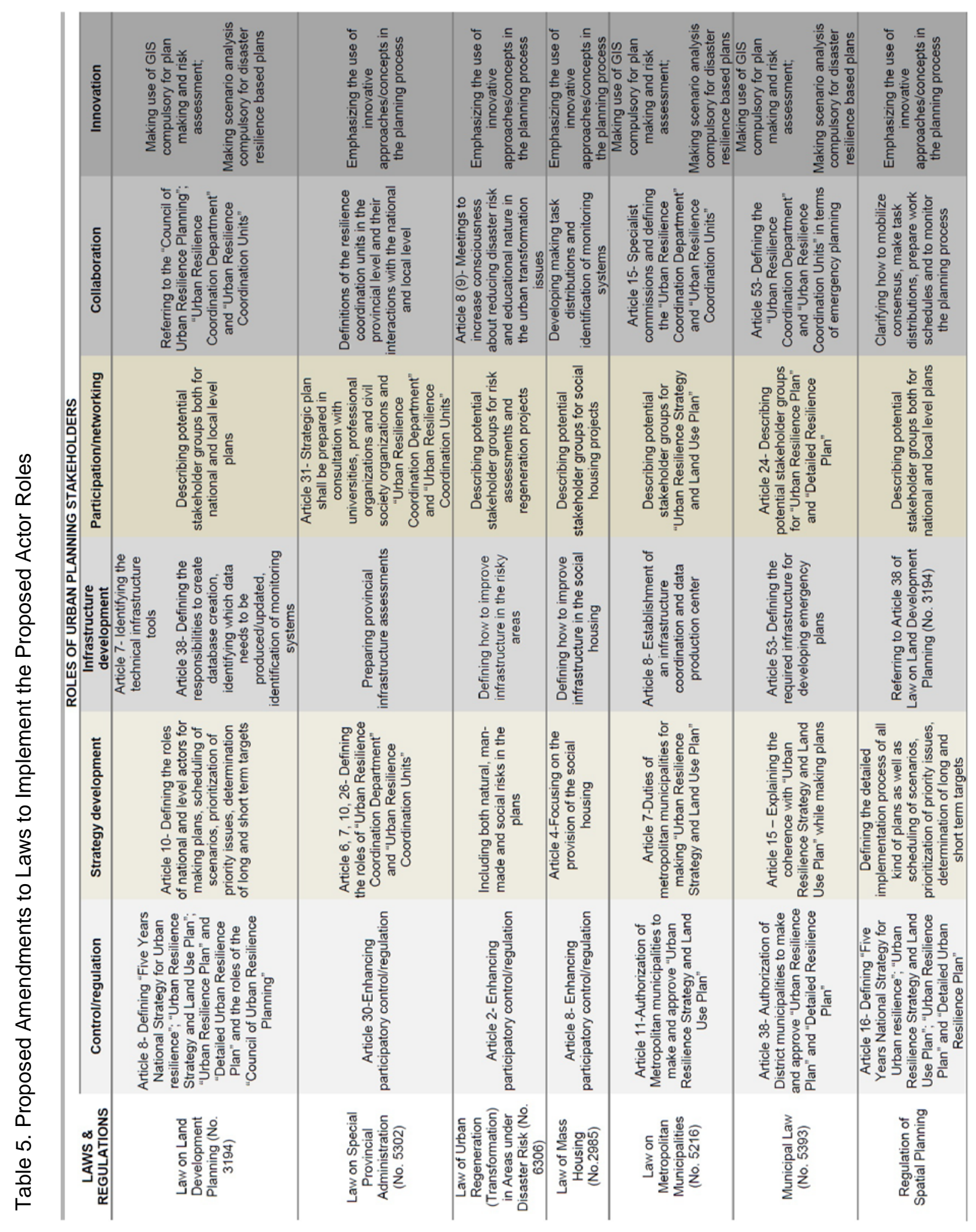

Through these amendments, the legislative system can serve for the implementation and preservation of urban resilience. Proposed actor-mapping can enhance the governance capacity, since it suggests a more organized and participatory management system. Accordingly, the gaps in the legislative system and governance capacity insufficiencies can be achieved. 


\section{Conclusion}

The paper proposed a formulation for resilience-related legislative and urban planning system in Turkey. The "urban resilience planning process" projected as the "five elements process" is a unique scheme referring to upgrade and update sustainable urban development through the provision of dynamism to the existing urban planning system. Bearing in mind the confusing urban planning stakeholders with intersecting authorization, urban resilience planning process proposed the identification of the actors as well as their roles and sources, which is a platform serving a collaborative method to provide the participation of diverse urban planning actors. The contribution of the paper can be grouped in three key categories:

1. defining an updated urban planning process and positioning it in the existing urban planning hierarchy,

2. configuring an actor roles scheme to increase governance capacity and

3. defining the legislative tools of "urban resilience planning".

Comparing to the existing urban planning process with lack of expert view, public participation and role definitions, the urban resilience planning process suggests effective problem definition, sufficient participation and collaboration through the Expert Opinion, Public Opinion and Policy Delphi Surveys. It is possible to emphasize that it is recommendable to apply a third or a fourth round of Delphi Survey in order to clarify the consensus for the implementation of the required urban resilience policies. The suggested outcomes related with the legal basis contain how to include the comprehensive actormapping scheme and how to improve the insufficiencies of governance capacity, which were compiled from the questionnaire results. The suggestions about the actor-mapping presents authorization scale, roles and tools of urban planning stakeholders.

The results of the five elements process proposed an ideal actor-mapping to overcome insufficient governance capacity in Turkey. Introducing the "five elements" to the urban planning process presents a platform to achieve the dual planning structure of Turkey. This dual structure refers to a regulatory method in theory and project-led in practice which is unsustainable and doesn't support and meet the needs of the city in any dimension. The process created dynamism with participation, feed backs, an on-going monitoring provided by resilience coordination units and new law amendments which would guarantee the implementation and continuity of resilient policies, while avoiding this duality. With this regard, it's possible to say that, integrating urban resilience in the existing planning hierarchy and the legislative system could be the most preferable revolution for the provision of resilient urban planning in Turkey.

To conclude, the following step should be the immediate accomplishment of the administrative restructuring for the implementation of urban resilience planning process in Turkey. Primarily, Ministry of Environment and Urbanism with collaboration of its provincial representatives, metropolitan municipalities, chambers and universities can be in charge of this step. Initially, the necessary arrangements can be prepared in the regulations and laws. This can follow a gradual process, since it will surely necessitate a detailed work for urban resilience planning process to gain an official status, then to prepare and to implement urban resilience plans. Hence, "urban resilience planning" and all related context will have a legal status. 


\section{REFERENCES}

Alberti, M. (2013). Planning Under Uncertainty: Regime Shifts, Resilience, and Innovation in Urban Ecosystems. Retrieved January 22, 2013, from http://www.thenatureofcities.com/2013/01/22/planning-under-uncertainty-regime-shiftsresilience-and-innovation-in-urban-ecosystems/.

Berkes, F., Folke, C., Colding, J. (Eds.) (1998). Linking Social and Ecological Systems, Management practices and social mechanisms for building resilience, Cambridge University Press.

Cornel, L. and Mirela L. (2008), Delphi - The Highest Qualitative Forecast Method, Buletinul Universităţii Petrol - Gaze din Ploieşti Seria Ştiinţe Economice No. 1 LX, 31 - 36.

Cutter, S.L., Barnes, L., Berry, M., Burton, C., Evans, E., Tate, E., Webb, J. (2008). A placebased model for understanding community resilience to natural disasters, Global Environmental Change 18, 598-606.

Ertugal, E. (2017). Challenges for Regional Governance in Turkey: The Role of Development Agencies, METU JFA 34 (2), 203-224.

Gotham, K.F. and Campanella, R. (2010). Toward a Research Agenda on Transformative Resilience: Challenges and Opportunities for Post-Trauma Urban Ecosystems, Critical Planning Summer 2010, 9-23.

Holling, C.S. (2001). Understanding the complexity of economic, ecological and social systems, Ecosystems 4, 390-405.

Istanbul Development Agency (ISTKA) (2010). 2010-2013 Istanbul Regional Plan. Retrieved November 27, 2014, from http://www.istka.org.tr/content/pdf/3---2010-2013-IstanbulRegional-Plan.pdf, Istanbul.

Istanbul Development Agency (ISTKA) (2014). 2014-2023 Istanbul Regional Plan. Retrieved November 27, 2014, from http://www.istka.org.tr/content/pdf//stanbul-Regional-Plan-20142023.pdf, Istanbul.

Istanbul Metropolitan Municipality (2009). 1/100.000 Scale Istanbul Metropolitan Land Use Plan Report, Retrieved November 27, 2014, from http://www.planlama.org/index.php/haberler/guncelhaberler/1180-1100000-oelcekli-stanbulcevre-duezeni-plan-ve-plan-raporu.

Karakayacı, Ö. (2015). Relational and Institutional Approaches to Planning Issues in Turkey, Megaron 10 (4), 580-594.

Law of Mass Housing Number 2985. (1984). Official Gazette, 18344, 17 March 1984.

Law of the Establishment of Regional Development Agencies Number 5449. (2006). Official Gazette, 26239, 25 January 2006.

Law of Urban Regeneration (Transformation) in Areas under Disaster Risk Number 6306. (2012). Official Gazette, 28309, 31 May 2012. 
Law on Land Development Planning and Control 3194. (1985). Official Gazette, 19749, 3 May 1985.

Law on Metropolitan Municipality Number 5216. (2004). Official Gazette, 25531, 10 July 2004.

Law on Special Provincial Administration Number 5302. (2005). Official Gazette, 25745, 4 March 2005.

Law on Tourism Encouragement 2634. (1982). Official Gazette, 17635, 16 March 1982.

Law no 5793 amending some Laws and Decree Laws (2008). Official Gazette, 26959, 6 August 2008.

Municipal Law Number 5393. (2005). Official Gazette, 25874, 13.07.2005.

Müller, B. (2010). Urban and Regional Resilience - A new catchword or a consistent concept for research and practice? Remarks Concerning the International Debate and the German Discussion. In B. Müller (Eds.), German Annual of Spatial Research and Policy 2010 (pp. 113). Berlin: Springer.

Novotny, V., Ahern, J., Brown, P. (2010). Water Centric Sustainable Communities: Planning, Retrofitting and Building the Next Urban Environment. Hoboken, NJ: J. Wiley.

The Bosphorus Law 2960 (1983). Official Gazette, 18229, 22 November 1983.

The Gecekondu Law 775 (1966). Official Gazette, 12362, 30 July 1966.

The Industrial Zones Law 4737 (2002). Official Gazette, 24645, 19 January 2002.

The Land and Soil Conservation Law 5403 (2005). Official Gazette, 25880, 3 July 2005.

The Law on the Organization and Duties of the Ministry of Environment and Forests 4856 (2003). Official Gazette, 25102, 8 May 2003.

The Ministry of Development (2019). The Eleventh Development Plan (2019-2023), Retrieved July 13, 202 from http://www.kalkinma.gov.tr/

The National Parks Law 2873 (1983). Official Gazette, 18132, 11 August 1983.

The Organized Industrial Zone Law 4562 (2000). Official Gazette, 24021,15 April 2000.

The Regulation on Spatial Planning (2014). Official Gazette, 29030, 14 June 2014.

The Shore Law 3621 (1990). Official Gazette, 20495, 17 April 1990.

The Statutory Decree No. 383 on Establishment of Special Environmental Protection Agency Presidency (1989). Official Gazette, 20341, 13 November 1989.

The Technology Development Zones Law 4691 (2001). Official Gazette, 24454, 26 June 2001.

The Village Law 442 (1924). Official Gazette, 68, 7 April 1924. 
Türk, Ş.Ş. (2002). The realization of the detailed local plans in urban areas in Turkey: a model, Proceedings of the $42^{\text {nd }}$ Congress of the European Regional Science Association: "From Industry to Advanced Services- Perspectives of European Metropolitan Regions", Dortmund, Germany 27-31 August, European Regional Science Association (ERSA), Louvain-laNeuve.

Ünsal, F. and Türk, Ş.Ş. (2014). Legal and Institutional Context of Urban Planning and Urban Renewal in Turkey: Thinking about Istanbul. In G. Erkut and M.R. Shirazi (Eds.), The Case of Beyoğlu, Istanbul Dimensions of Urban Re-development (pp. 15-31). Endformat $\mathrm{GmbH}$, Berlin.

Üstündağ, Ö. and Şengün, M.T. (2011). Türk İmar Mevzuatındaki Plan Türleri ve Fiziki Planlama - Coğrafya İlişkisi Üzerine Genel Bir Değerlendirme, Fırat Üniversitesi Sosyal Bilimler Dergisi 21 (2), 1-25.

Uzun, N. (2010). Urban governance in Istanbul, Análise Social 45, (197), 757-770.

Yomralığlu, T. and Ülger, N.E. (2014). An Assessment on Applications of Development Plans in Turkey, In Proceedings of the FIG Congress 2014- Engaging the Challenges Enhancing the Relevance, Kuala Lumpur, Malaysia 16-21 June.

Wikström, A. (2013). The Challenge of Change: Planning for social urban resilience: An analysis of contemporary planning aims and practices. (Master Thesis) Stockholm University, Urban and Regional Planning, Department of Human Geography, STOCKHOLM.

Yaman-Galantini, Z.D. (2018). Urban Resilience as a Policy Paradigm for Sustainable Urban Planning and Urban Development: The case of Istanbul. PhD Thesis, Istanbul Technical University, Turkey.

Yousuf, M.I. (2007). Using Experts' Opinions through Delphi Technique, Practical Assessment, Research \& Evaluation, 12 (4).

Zhao P., Chapman R., Randal E., Howden-Chapman P. (2013). Understanding Resilient Urban Futures: A Systemic Modelling Approach, Sustainability 5, 3202-3223.

Url-1<http://istanbul.csb.gov.tr/ilimiz-bagcilar-ilcesi-cinar-inonu-sancaktepe-yavuzselim-vemerkez-mahallelerinin-bir-kismini-kapsayanriskli-alana-yonelik-hazirlanan-1-5000-olceklibagcilar-meydani-kentsel-donusum-alani-nip-ve-1-1000-olcekli-bagci-duyuru-193489>, date retrieved 02.05.2018.

Url-2<http://istanbul.csb.gov.tr/istanbul-ili-beyoglu-ilcesi-camiikebir-mahallesinde-bulunanozel-proje-alanina-iliskin-hazirlanan-1-5000-olcekli-koruma-amacli-nip-degisikligi-ve-1-1000olcekli-koruma-amacli-uip-degisikligine-iliskin-aski-ilani-duyuru-55948>, date retrieved 02.05.2018. 